\title{
The Peculiarity of E-Learning XHTML Editor (EXE) Based on Attention, Relevance, Confidence, Satisfaction (ARCS) to Improve the Students' Learning Motivation of Vocational High School
}

\author{
Luthfi Isna Nur Aini ${ }^{1}$, Siswandari ${ }^{1}$, Hery Sawiji ${ }^{1}$ \\ ${ }^{1}$ Student of Master’s Degree Program in Economics Education, Sebelas Maret University, Surakarta, \\ Indonesia \\ Email: luthfi.isna@yahoo.co.id
}

\begin{abstract}
The modern advancement of technology has changed the way people live, the way people communicate, and the way people learn. Moreover, the technology appearing in the field of education, especially for Vocational High School students in using technology as a medium of learning to improve student learning motivation. The use of technology in the education field with good criteria can bring new effects for students, therefore media that can be designed by teachers is needed in order to develop learning materials without the need for expertise in programming language, that is EXE. The use of technology as a learning media can be integrated with ARCS to generate student motivation, especially in Vocational High School. The purpose of this article is to examine the peculiarities of EXE based on ARCS to improve the students' motivation in Vocational High School. The writing method of this article is a review of relevant research journal literature. The peculiarity of EXE based on ARCS is in every student's interest in learning the subjects. In addition, this media can be used for the students to build initial knowledge in understanding the concept of learning, so that it can be used in solving the problems given by teachers.
\end{abstract}

Keywords: EXE; ARCS; learning motivation.

\section{INTRODUCTION}

The modern advancement of technology gives impacts for the most aspects of life. One of the impacts of technological advancement is the educational aspect. Now days, education is required to utilize technology as a media to improve education to create a smart nation. This is in accordance with the objectives of the national education listed in Law No. RI. 20 of 2003 Article 3, namely:

"National education aims to develop the ability and create the character and civilization of a dignified nation in order to educate the nation's life, aims to develop the potential of learners to be a human being who believes and pious to God Almighty, noble, healthy, knowledgeable, skilled, creative, Independent, and become a democratic and responsible citizen” 
The way to know the improvement of education, especially at the level of SMK is from the average score of the UN. The data on the average score of UN in 2015, the average score is 62.11 and in 2016 the average score is 57.66 or decreased 4.45 points [1]. The decreased average score in the national exam in 2016 is due to many factors that must be promptly researched and followed up to improve the results of the national exam in the next year.

One of the efforts to follow up the improvement of education in Indonesia is by improving the learning process. Learning process is one part that can not be separated from education. The learning process is a complex activity involving various learning support components to create a system, so that the learning objectives can be achieved.

One of the supporting components of the learning process that can be used to convey information from the teachers to the students is the media learning. Learning media is the tools or tools used in delivering the learning messages [2] [3]. Learning can be organized smoothly, efficiently, and effectively if the teachers and the students are able to utilize learning media. It is contained in Permendiknas RI No. 40 of 2008 on Standards of Facilities and Infrastructure for Vocational High School/Madrasah Aliyah Kejuruan (SMK/MAK) that the educational media is a tool used to assist communication in learning. The existence of learning media for the teachers and the students in the classroom or outside the classroom makes the subject matter provided by the teacher can be accepted more optimally and efficiently by the students. E-learning XHTML Editor (EXE) is an application created for the teachers to make easier in designing learning media. According to Mussoi, Flores, Bulegon, \& Tarauco [4], EXE is an authoring program, which the teachers can develop in publishing learning materials without the need for programming language skills. However, good learning media should include the elements of motivation therein, in accordance with Wena [5] which states that the development of learning media are expected to motivate the students, so the level of understanding of the students who tend to be low will increase and there is an improvement in student learning outcomes. ARCS-based EXE learning media is considered very strategic to be developed.

Attention, Relevance, Confidence, Satisfaction (ARCS) is one of the learning models popularized by Keller and used to improve learning motivation and used in learning media. The above is supported by Suzuki, Nishibuchi, Yamamoto \& Keller [6] that the ARCS model aims to create guidance for the students to be more interested in learning activities. The provision of interesting clues is expected to affect the motivation to learn, so that learning objectives can be achieved. Learning media that contains the elements of motivation is designed so that each student in learning can be interested in studying these subjects. It aims that at the end of learning, the students can learn more independently in accordance with the instructions that exist and it affects to the students' learning outcomes. Thus, the writer would like to discuss about the peculiarity of ELearning XHTML Editor (EXE) based on Attention, Relevance, Confidence, Satisfaction (ARCS) to improve the students' learning motivation of Vocational High School. 


\section{METHOD}

The method used in this article is a study of literature with the aim of providing knowledge of the peculiarities of learning media using EXE integrated with ARCS to improve the student' learning motivation. The study that contributed to this article is from various journals accessed through online sites that amount to more than 20 journals related to the EXE discussion. The focus in this study is not only on the improve the learning motivation caused by EXE, but also on other findings besides that. Then the findings will be reflected in the form of results.

\section{DISCUSSION}

\section{E-Learning XHTML Editor (EXE)}

EXE is an authoring program which the teachers can develop the learning materials without the need for expertise in programming languages such as HTML, XML, or web application programming capabilities [7] [8] [9], so that teaching materials become more attractive to the students [10]. EXE is structured hierarchically and systematically covering topics, sections, and units [11]. Creating content on EXE is by presenting a learning framework based on the needs of the users or teachers, they can create from the node structure associated with other nodes, so that the students can understand the material presented in EXE [12]. EXE can be made tutorial materials, questions with multiple choice types, short answers, correct and wrong quiz that can be used for the student competency test, [13]. The opensource software is free to apply and can be downloaded on Windows, Linux and Macintosh operating system versions [14]. In addition, the EXE Program is developed as an offline-based authoring that requires low bandwidth. Media EXE is expected to be a supporter of easy, renewable, and petrified learning media for the teachers [15].

Some advantages in the use of EXE in learning activities by Priyambodo [16] are as follows:

a. Easy to use even if the user does not know the programming language.

b. WYSIWYG (What You See Is What You Get) makes easy in designing because the results on the screen look exactly like the final result when published.

c. Free (free) and open source software.

d. E-learning standard (SCORM).

e. Can be used in both Windows and Linux operating systems

Other advantages are according to WebLearn [17] from the use of EXE are as follows.

a. EXE is a tool arranged sequentially for online learning activities.

b. EXE offers activities content that can be arranged sequentially and forked.

c. Provide an easy dialog menu by copying or pasting from word.

d. Can display equations, images without using HTML or web authoring tools.

e. Can be integrated with external websites. 
f. It is easy to use to create multiple choice questions and quizzes with different types of questions.

g. User can change the look provided by EXE.

h. The content of the subject can be exported using WebLearn.

\section{Attention, Relevance, Confidence, Satisfaction (ARCS)}

A form of problem solving approach to design motivation aspects and learning environment is the ARCS model approach (Attention, Relevance, Confidence, and Satisfaction), (Keller, 1987). Molaee \& Dortaj [18], state that ARCS is a suitable model for designing strategies in analyzing motivation, whereas according to Huett et al [19], ARCS is a model for behaviour, cognitive, and affective that can show that students' learning motivation is influenced through external conditions. ARCS can be used for the students to build their initial knowledge in constructing knowledge acquired by the students in understanding the concept of learning, so that it can eventually be used in solving problems given by the teachers [20].

The purpose of ARCS model by Suzuki, Nishibuchi, Yamamoto \& Keller [21] is to make the instruction for the students to be more interested in learning activities. The provision of interesting clues is expected to affect the motivation to learn, so that learning objectives can be achieved. This is in line with the opinion of Colakoglu \& Akdemir [22], ARCS is used to guide instructional design and the teachers to develop learning in integrating into motivational design. Learning developed on the basis of ARCS can increase the student's attention during learning, develop relevance to the student's needs, create positive expectation for success and have satisfaction in success [23].

ARCS is an acronym of a student's attitude of attention, relevance, confidence, and satisfaction which is a component of ARCS. Some of these components are:

\section{a. Attention}

The student's attention refers to the student's sense of curiosity in the concept [24]. There is sub components in the attention, that is the student's passion during perception, giving challenging questions or problems to be solved, and brainstorming, while according to Wena [25], there are three components of strategy to generate the student's attention in learning activities, they are: 1) generate the perception of the student, that is by using a new thing, inappropriate, or by giving sudden stimulus changes, (2) cultivate desire to research, that is by stimulating the student's behaviour to find information by asking problem or problem solving, and (3) use various learning elements, with variation of text formatting, presenting various images, and various colour. The existence of variations aimed at the students, the students are expected to focus more and focused on learning. 


\section{b. Relevance}

Relevance relates to learning materials presented to the needs and conditions of the students [26]. Learning materials and concepts are made in such a way to make it be familiar with the students, namely with concrete examples related to the student's work, whereas according to Wena [27], to improve relevance the needs of students, there are three strategies, namely (1) make familiarity and good habit, namely learning is done by using and use of concrete language and concept related to the experience of student life value, (2) present the goal-oriented learning side, that is by presenting examples or statements related the purpose and usefulness of learning, and (3) use appropriate strategies, according to the characteristics of the students in which the teacher should understand the level of student development, learning habit, and cognitive style.

\section{c. Confidence}

The aspect of confidence in ARCS model according to Malik [28] is focused on building positive expectations to achieve success among students. The level of the student's confidence is closely related to the level of the student's learning motivation so that the students will feel able to complete the tasks and expectations succeed in learning. In line with the opinion of Siregar \& Hartini [29] that motivation will increase with increasing self-confidence, that is through (1) increasing the students' expectations to succeed by multiplying successful experiences, (2) organizing learning into smaller parts so that the students are not required to study many materials at once, (3) making the students' self-confidence appeared with constructive statements, and (4) provide constructive feedback during the learning process so that the students know the extent to which the students' understanding and learning outcomes.

\section{d. Satisfaction}

Aspect of satisfaction consists of several components [30] namely: (1) provide problems, stimulation, or examples of work showing the students that the students can solve the problem of "real world", (2) Provide rewards that are in form of verbal or symbolic rewards (3) make criteria that are consistent with stated expectations and make consistent measurement standards. Thus, the students will feel satisfied and motivated in every doing or completing learning tasks.

\section{Learning Motivation}

When viewed from the aspect of teachers, learning process activities are designed in the instructional design of teachers to students in the school, while in terms of students, learning activities carried out activities because the students' desires arise from within the students. This is what makes learning motivation plays an important role in the 
learning process. Motivation is seen as a direction and how much behaviour or motivation is an indicator of business [31], whereas according to Do"rnyei \& Skehan [32] motivation is a response of a person to decide something, how to do his activities, and how hard someone is in doing something. Motivation arises from an impulse arising from within an individual and can encourage the individual to achieve the individual expectation [33] [34]. In the learning activities, the effort indicators are reflected in the involvement of the students on the various tasks performed effectively and will affect the students' learning motivation [35] [36].

There are two factors of motivation [37] [38] [39] [40] [41], namely intrinsic and extrinsic factors. Intrinsic factor is motivation that affects the students with their awareness to learn, have curiosity, and have tendency to choose challenges in order to achieve scientific goals. Extrinsic factor is the external factor of the students that affects the students' interests, attitudes toward learning experiences such as the influence of teachers, the desire to get maximum results and avoid punishment. The presence of a strong motivation motivation in doing every activity, especially learning for the students, it will make the students' learning goals achieved.

Motivation in the education field in particular is one of the key considerations in the students' learning activities, [42] [43]. Students who have motivation in learning according to Sardiman [44], have the following characteristics:

a. Students are diligent in doing the tasks, in this case the students continuously in a long time will not stop doing the tasks before the tasks are completed.

b. Students are tough in facing the difficulties or do not quickly give up, in this case the students do not feel quickly satisfied with the achievements obtained and do not require the motivation others.

c. Students show interest in various problems.

d. Students prefer to work independently.

e. Students get bored quickly with routine, repetitive tasks that are less creative.

f. Students can defend their opinions if they are sure of something they are learning.

g. Students are not easily affected to release what is deemed to be true by students.

h. Students are happy to find and solve problems.

Besides, there is also the opinion of one of the educational experts who describe the motivation of learning indicators in terms of external and internal. Without the desire, encouragement of needs, and the desire of students in learning, the students are not excited and active in learning activities. The learning motivation indicators according to Uno [45], namely:

"Learning motivation is internal and external encouragement to students who are learning to change behaviour, generally with some supportive indicators or elements. It has a great role of being successful in learning. Indicators of learning motivation can be classified as follows:(1) passion and desire to be successful, (2) encouragement and need for learning, (3) future expectations and ideals, (4) learning appreciation, (5) interesting teaching and learning activities, and (6) conducive learning environment.” 
The peculairity E-Learning XHTML Editor (EXE) Based on Attention, Relevance, Confidence, Satisfaction (ARCS) to improve the students' learning motivation in Vocational High School

The development of science and technology in the education filed in particular can encourage the teachers to adjust to the existence of these technologies by utilizing these technologies in the learning process. Teachers are required to use the availability of tools provided by the school as a supporting media in learning and develop skills in making learning media that will be used if the media is not yet available. In this case, the role of learning media is needed by the teacher to support in delivering the materials to the students [46]. This is in line with the opinion of Taiwo [47], he states that the media used as a complement by the teacher as a form of effectiveness in the classroom and as a substitute media in the system of learning media.

Implementation of learning technology is very important. Students will be more interested in learning that utilizes learning media because it can increase students' activities and creativities, especially for the students' of Vocational High School students who are not only required to be able to master the material in terms of hard skills. Vocational High School students are more required for mastery of the material in terms of soft skills that will be prepared to face the workforce after graduation. Therefore, the use of learning media is very necessary for them.

One of the media used is the use of computer media by teachers, they will be easier to convey material that is difficult to imagine by the students into a concept that can be understood and even interesting for the students [48]. Computer media with utilizing software is by using software EXE (E-learning XHTML Editor). EXE Software is an application that is used for the manufacture of teaching materials based on e-learning [49] [50] [51], EXE can be a teacher as a tool that allows to teach by creating educational content without knowing the HyperText Mark up Language (HTML) programming language. EXE learning media can present more interesting material both audio and visual [52]. Besides, EXE programme is also suitable as e-module software that can be downloaded easily and free [53]. Another criterion of EXE media is the use of interactive EXErcises developed with open source authoring applications that can improve the students' performances compared to traditional EXErcises [54] [55] [56] [57] state that with EXE media, the students are more likely to understand the concepts of learning materials and can eliminate boredom in learning. In addition, the most students become interested and motivated in learning [58].

The use of technology in the education filed especially EXE software that has good criteria can bring new effect for the students [59] and have positive impact in improving the students' learning motivation [60] [61] [62] [63] [64] [65]. The students' high motivation will affect the students' achievement [66].

The use of technology as a medium of learning today has not been integrated with the model of learning that can improve the students' learning motivation. [67] [68] [69] [70] [71], motivation influences the students with their awareness to learn, have curiosity, and have tendency to choose challenges in order to achieve the learning goals. Thus, EXE media can be integrated with ARCS which is proven to be effective in 
learning [72]. According to Colakoglu \& Akdemir [73], ARCS can assist the teachers in developing learning that is integrated with the motivational design strategy in order to provide instructions that are easy for the students [74] [75] [76], thus, the ARCS strategy can be used to improve the students' tmotivation and learning outcomes [77] [78] [79]. Besides, there is a difference in learning outcomes between the students using the ARCS learning model and the students using the conventional learning model and the students' learning outcomes are higher using the ARCS learning model [80].

\section{CONCLUSION}

Based on the discussion above, the peculiarity of E-Learning XHTML Editor (EXE) based on Attention, Relevance, Confidence, Satisfaction (ARCS) is to improve the students' learning motivation in Vocational High School in which learning media containing motivational elements are designed so that each student in studying will be interested in studying these subjects. In addition, this media can be used for the students to build their initial knowledge in constructing knowledge obtained by the students to understand the concept of learning, so that it ultimately can be used in solving the problems given by teachers.

\section{REFERENCES}

[1] Medistiara, Y. (2016, 9 Mei). Nilai Rata-rata UN SMA 2016 Turun 6 Poin dari Tahun 2015. Detiknews. Diperoleh 18 Maret 2017, dari http://news.detik.com/berita/d-3206228/nilai-rata-rata-unsma-2016-turun-6-poin-dari-tahun-2015.

[2] Arsyad, A. (2010). Media Pembelajaran. Jakarta: PT Rajagrafindo Persada.

[3] Daryanto. (2011). Media Pembelajaran. Bandung: PT Sarana Tutorial Nurani

[4] Mussoi, E. M., Flores, M. L. P., Bulegon, A. M., \& Tarouco, L. M. R. (2011). GeoGebra and EXE Learning Applicability in the Teaching of Physics and Mathematics. Systematics, Cybernetics, and Informatics. 9 (2) 61-66.

[5] Wena, M. (2014). Strategi Pembelajaran Inovatif Kontemporer: Suatu Tujuan Konseptual Operasional. Jakarta: Bumi Aksara.

[6] Suzuki, K., Nishibuchi, A., Yamamoto, M., \& Keller, J.M. (2004). Development and Evaluation of Website to Check Instructional Design Based on the ARCS Motivation Model. Ministry of Education, Culture, Sport, Science and Technology: Grants-in-Aid for Scientific Research, 2

[7] Warjana dan Razaq, A. (2009). Membuat Bahan Ajar Berbasis Web dengan EXE. Jakarta : Elexmedia Komputindo.

[8] Mussoi, E. M., Flores, M. L. P., Bulegon, A. M., \& Tarouco, L. M. R. (2011). GeoGebra and EXE Learning Applicability in the Teaching of Physics and Mathematics. Systematics, Cybernetics, and Informatics. 9 (2) 61-66.

[9] Ardliabzi (2013, 5 Juni). Keuntungan Menggunakan Tools EXE Learning. Diperoleh 17 Februari 2017, dari http://ardliabzi.blogspot.co.id/2013/06/kelebihan-menggunakan-tools-EXE-learning.html.

[10]Copriady, J. ( 2014). Penerapan SPBM yang Diintegrasikan Dengan Program EXE Learning Terhadap Motivasi Hasil Belajar Mahasiswa Pada Mata Kuliah Kimia Dasar. Jurnal Pendidikan 5 (2) 95-105. 
[11] Priyambodo, E. (2010). Pemanfaatan Program Aplikasi EXE (Elearning WHTML Editor) Dalam Penyususnan Media Pembelajaran Di Sekolah. Prosiding Seminar Nasional Penelitian, Pendidikan dan Penerapan MIPA. Yogyakarta: Fakultas MIPA, Universitas Negeri Yogyakarta.

[12]Bulegon, A. M. \& Tarouco, L. M. (2012). EXE Learning and Learning Objects: Resources for Teaching Assistants in Physics. IADIS International Conference e-Learning. Portugal: Part of the IADIS Multi Conference on Computer Science and Information Systems.

[13]Copriady, J. ( 2014). Penerapan SPBM yang Diintegrasikan Dengan Program EXE Learning Terhadap Motivasi Hasil Belajar Mahasiswa Pada Mata Kuliah Kimia Dasar. Jurnal Pendidikan 5 (2) 95-105.

[14] Mussoi, E. M., Flores, M. L. P., Bulegon, A. M., \& Tarouco, L. M. R. (2011). GeoGebra and EXE Learning Applicability in the Teaching of Physics and Mathematics. Systematics, Cybernetics, and Informatics. 9 (2) 61-66.

[15] Nurdin, S. dan Setiawan, W. (2016). Improving Students' Cognitive Abilities And Creative Thinking Skills On Temperature And Heat Concept Through An EXElearning-Assisted Problem Based Learning. International Journal of Scientific \& Technology Research, 5 (12), 59-63.

[16] Priyambodo, E. (2010). Pemanfaatan Program Aplikasi EXE (Elearning WHTML Editor) Dalam Penyususnan Media Pembelajaran Di Sekolah. Prosiding Seminar Nasional Penelitian, Pendidikan dan Penerapan MIPA. Yogyakarta: Fakultas MIPA, Universitas Negeri Yogyakarta.

[17]WebLearn. (2011, 22 Februari). How to Create Content Using EXE. Diperoleh 16 Februari 2017, dari http://creativecommons.org/licenses/by-sa/3.0/.

[18] Molaee, Z \& Dortaj, F. (2015). Improving L2 Learning: An ARCS Instructional-Motivational Approach. Procedia: Social and Behavioral Science, 171, 1214-1222.

[19]Huett, J. B., Kalinowski, K. E., Moller, L., \& Huett, K. C. (2008). Improving the Motivation and Retention of Online Students Through the Use of ARCS-Based E-Mails. The Amer: Journal of Distance Education, 22, 159-176.

[20]Winaya, I. M. A., Lasmawan, W., \& Dantes, N. (2013). Pengaruh Model ARCS Terhadap Hasil Belajar Ditinjau dari Motivasi Belajar Siswa Pada Pembelajaran IPS di Kelas IV SD Chis Denpasar. Program Studi Pendidikan Dasar: e-Journal Program Pascasarjana Universitas Pendidikan Ganesha, 3.

[21] Suzuki, K., Nishibuchi, A., Yamamoto, M., \& Keller, J.M. (2004). Development and Evaluation of Website to Check Instructional Design Based on the ARCS Motivation Model. Ministry of Education, Culture, Sport, Science and Technology: Grants-in-Aid for Scientific Research, 2

[22] Colakoglu, O.M \& Akdemir, O. (2010). Motivational Measure Of The Instruction Compared: Instruction Based On The Arcs Motivation Theory V.S. Traditional Instruction in Blended Courses. Turkish Online Journal of Distance Education-TOJDE, 11 (2), 73-89.

[23] Malik, S. (2014). Effectiveness of ARCS Model of Motivational Design to Overcome Non Completion Rate of Students in Distance Education. Turkish Online Journal of Distance Education TOJDE, 15(2), 194-200.

[24]Malik, S. (2014). Effectiveness of ARCS Model of Motivational Design to Overcome Non Completion Rate of Students in Distance Education. Turkish Online Journal of Distance Education TOJDE, 15(2), 194-200.

[25]Wena, M. (2014). Strategi Pembelajaran Inovatif Kontemporer: Suatu Tujuan Konseptual Operasional. Jakarta: Bumi Aksara.

[26] Keller, J. M. (2010). Motivational Design for Learning and Perfomance: The ARCS Model Approach. London: Springer New York Dordrecth Heidelberg.

[27]Wena, M. (2014). Strategi Pembelajaran Inovatif Kontemporer: Suatu Tujuan Konseptual Operasional. Jakarta: Bumi Aksara.

[28]Malik, S. (2014). Effectiveness of ARCS Model of Motivational Design to Overcome Non Completion Rate of Students in Distance Education. Turkish Online Journal of Distance Education TOJDE, 15(2), 194-200.

[29] Siregar, E., \& Hartini, N. (2011). Teori Belajar dan Pembelajaran. Bogor: Ghalia Indonesia.

[30] Keller, J. M. (2010). Motivational Design for Learning and Perfomance: The ARCS Model Approach. London: Springer New York Dordrecth Heidelberg. 
[31] Kutu, H. \& Sozbilir, M. (2011). Adaption of Instructional Materials Motivation Survey to Turkey: A Validity and Reliability Study. Necatibey Faculty of Education Electronic: Journal of Science and Mathematics Education, 5 (1) 292-312.

[32]Do“ rnyei, Z., \& Skehan, P. (2003). Individual differences in second language learning. In C. L. Doughty \& M. H. Long (Eds.), The handbook of second language acquisition (pp. 589-630). Malden, MA: Blackwell.

[33]Bakar, R. (2014). The Effect of Learning Motivation On Student's Productive Competencies In Vocational High School, West Sumatra. International Journal of Asian Social Science, 4 (6), 722732.

[34] Dimyati \& Mudjiono. (2013). Belajar \& Pembelajaran. Jakarta: P.T Rineka Cipta.

[35]Chang, C., Chang, C, K., \& Shih, J.L. (2016). Motivational Strategies in Mobile Inquiry-Based Languange Learning Setting. System, 59, 100-115.

[36] Gomez, E. A., Wu, D., \& Passerini, K. (2010). Computer-Supported Team-Based Learning: The Impact of Motivation, Enjoyment, and Team Contribution on Learning Outcomes. Computer \& Education, 55, 378-390.

[37] Carenys, J., Moya, S., \& Perramon, J. (2016). Is It Worth It to Consider Videogames in Accounting Education? A Comparison of Simulation and A Videogames in Attributes, Motivation, and Learning Outcome. Spanish Accounting Review. 1-13.

[38]Chang, C., Chang, C, K., \& Shih, J.L. (2016). Motivational Strategies in Mobile Inquiry-Based Languange Learning Setting. System, 59, 100-115.

[39] Gomez, E. A., Wu, D., \& Passerini, K. (2010). Computer-Supported Team-Based Learning: The Impact of Motivation, Enjoyment, and Team Contribution on Learning Outcomes. Computer \& Education, 55, 378-390.

[40] Kim, K., J. \& Frick, T., W. (2011). Changes In Student Motivation During Online Learning. Journal Educational Computing Research, 44 (1), 1-23.

[41]Harandi, S. R. (2015). Effects of e-Learning on Students' motivation. Procedia: Social and Behavioral, 181, 423-430.

[42] Brophy, J. (2004). Conceptualizing student motivation. Educational Psychologist, 18, 200-215.

[43] Molaee, Z \& Dortaj, F. (2015). Improving L2 Learning: An ARCS Instructional-Motivational Approach. Procedia: Social and Behavioral Science, 171, 1214-1222.

[44] Sadirman, A. S., Rahardjo, R., Haryono, A., \& Rahardjito. (2012). Media Pendidikan dan Pengertian, Pengembangan dan Pemanfaatannya. Depok: RajaGrafindo Persada.

[45]Uno, H. B. (2007). Teori Motivasi \& Pengukurannya. Jakarta: PT. Bumi Aksara.

[46] Sittichailapa, T., Rattanacha, R., \& Polvieng, P. (2015). The Development of Model Learning Media of Sorting Algoritm. 7th World Conference on Educational Sciences, (WCES-2015), 05-07 February 2015, Novotel Athens Convention Center, Athens, Greece.

[47] Taiwo, S. (2009). Teachers' Perception of The Rule of Media In Classroom Teaching In Secondary Schools. The Turkish Online Journal of Educational Technology-TOJET, 8 (1) 75-83.

[48]Copriady, J. ( 2014). Penerapan SPBM yang Diintegrasikan Dengan Program EXE Learning Terhadap Motivasi Hasil Belajar Mahasiswa Pada Mata Kuliah Kimia Dasar. Jurnal Pendidikan 5 (2) 95-105.

[49] Priyambodo, E. (2010). Pemanfaatan Program Aplikasi EXE (Elearning WHTML Editor) Dalam Penyususnan Media Pembelajaran Di Sekolah. Prosiding Seminar Nasional Penelitian, Pendidikan dan Penerapan MIPA. Yogyakarta: Fakultas MIPA, Universitas Negeri Yogyakarta.

[50] Mussoi, E. M., Flores, M. L. P., Bulegon, A. M., \& Tarouco, L. M. R. (2011). GeoGebra and EXE Learning Applicability in the Teaching of Physics and Mathematics. Systematics, Cybernetics, and Informatics. 9 (2) 61-66.

[51]Bulegon, A. M. \& Tarouco, L. M. (2012). EXE Learning and Learning Objects: Resources for Teaching Assistants in Physics. IADIS International Conference e-Learning. Portugal: Part of the IADIS Multi Conference on Computer Science and Information Systems.

[52]Copriady, J. ( 2014). Penerapan SPBM yang Diintegrasikan Dengan Program EXE Learning Terhadap Motivasi Hasil Belajar Mahasiswa Pada Mata Kuliah Kimia Dasar. Jurnal Pendidikan 5 (2) 95-105. 
[53] Yulinda, M. K. (2015). Peningkatan Pemecahan Masalah dan Hasil Belajar Matematika Melalui Aplikasi EXE (e-Learning XHTML editor) Pada Siswa Kelas VIIIE SMP Negeri 1 Geyer Tahun Ajaran 2015/2016. Naskah Publikasi, Universitas Muhammadiyah Surakarta.

[54] Akdemir, O., Kunt, K., \& Tekin, I. (2012). The Effects of Interactive EXErcises on Students' Achievement: Using the Open Source Authoring Application. Social and Behavioral Sciences, 55, 1009-1013.

[55] Rahayu, U. (2014). Pengembangan Media Pembelajaran Fisika Modul Kontekstual Interaktif Berbasis Website Offline dengan Penggunaan Program EXE Learning V-1.04.0 untuk SMA Kelas XI Pokok Materi Fluida, Skripsi Tidak Dipublikasikan, Universitas Sebelas Maret, Surakarta.

[56] Jahro, I. S., dan Ridho, D. (2015). Penerapan Model Problem Based Learning Menggunakan Media EXE Learning Untuk Meningkatkan Hasil Belajar dan Kerjasama Siswa Pada Materi Hodrokarbon. Jurnal Pendidikan Kimia, 7 (3) 80-86.

[57]Ulfa, A. M., Herdini, \& Rery, R., U. (2016). Penerapan Media EXE Learning untuk Meningkatkan Prestasi Belajar Siswa Pada Pokok Bahasan Struktur Atom dan Sistem Periodik Unsur di Kelas X SMA Negeri 9 Pekanbaru, Jurnal Online Mahasiswa (JOM) Bidang Keguruan dan Ilmu Pendidikan, $3(2), 1-9$

[58] Nurdin, S. dan Setiawan, W. (2016). Improving Students' Cognitive Abilities And Creative Thinking Skills On Temperature And Heat Concept Through An EXElearning-Assisted Problem Based Learning. International Journal of Scientific \& Technology Research, 5 (12), 59-63.

[59] Jeno, L. M., Grytnes, J. A., \& Vandvik, V. (2017). The Effect of A mobile-Application Tool on Biology Students' Motivation and Achievement in Spesies Identification: A Self-Determination Theory Perspective. Computer \& Education, 107, 1-12.

[60]Heafner, T. (2004). Using Technology to Motivate Students to Learn Social Studies. Contemporary Issues in Technology And Teacher Education, 4 (1) 42-53.

[61] Gomez, E. A., Wu, D., \& Passerini, K. (2010). Computer-Supported Team-Based Learning: The Impact of Motivation, Enjoyment, and Team Contribution on Learning Outcomes. Computer \& Education, 55, 378-390.

[62] Yamakawa, Y., Ohshiro, M., Matshushita, K., Mackin, K. J., dan Nunohiro, E. (2010). Programming Learning Support System 'CAPTAIN' with Motivational Study Model. Wong, S. L., et al. (Eds.). Proceedings of the 18th International Conference on Computers in Education. Putrajaya, Malaysia:Asia-Pacific Society for Computers in Education.

[63] Aini, S. S. Q. \& Sukirno. (2013). Pocketbook As Media of Learning to Improve students Learning Motivation. Jurnal pendidikan Akuntansi, 9 (2), 68-75.

[64]Harandi, S. R. (2015). Effects of e-Learning on Students' motivation. Procedia: Social and Behavioral, 181, 423-430.

[65]Fryer, L. K. dan Bovee, H. N. (2016). Supporting Students' motivation For E-Learning: Teachers Matter On and Offline. Internet and Higher Education, 30, 21-29.

[66] Afzal, H., Ali, I., Khan, M. A., \& Hamid, K. (2010). A Study of University Students' Motivation and Its Relationship with Their Academic Performance. International Journal of Business and Management, 5 (4), 80-88.

[67]Carenys, J., Moya, S., \& Perramon, J. (2016). Is It Worth It to Consider Videogames in Accounting Education? A Comparison of Simulation and A Videogames in Attributes, Motivation, and Learning Outcome. Spanish Accounting Review. 1-13.

[68]Chang, C., Chang, C, K., \& Shih, J.L. (2016). Motivational Strategies in Mobile Inquiry-Based Languange Learning Setting. System, 59, 100-115.

[69]Gomez, E. A., Wu, D., \& Passerini, K. (2010). Computer-Supported Team-Based Learning: The Impact of Motivation, Enjoyment, and Team Contribution on Learning Outcomes. Computer \& Education, 55, 378-390.

[70]Kim, K., J. \& Frick, T., W. (2011). Changes In Student Motivation During Online Learning. Journal Educational Computing Research, 44 (1), 1-23.

[71] Harandi, S. R. (2015). Effects of e-Learning on Students' motivation. Procedia: Social and Behavioral, 181, 423-430. 
[72] Fitrianingrum, A. (2015). Pengembangan Bahan Ajar Digital Berbasis ARCS (Attention-RelevanceConvidence-Satisfaction) untuk Meningkatkan Keefektifan Pembelajaran Jaritmatika Dengan Metode Blended Learning di Unit Jaritmatika Center Salatiga. Tesis Tidak Dipublikasikan, Universitas Sebelas Maret, Surakarta.

[73] Colakoglu, O.M \& Akdemir, O. (2010). Motivational Measure Of The Instruction Compared: Instruction Based On The Arcs Motivation Theory V.S. Traditional Instruction in Blended Courses. Turkish Online Journal of Distance Education-TOJDE, 11 (2), 73-89.

[74] Suzuki, K., Nishibuchi, A., Yamamoto, M., \& Keller, J.M. (2004). Development and Evaluation of Website to Check Instructional Design Based on the ARCS Motivation Model. Ministry of Education, Culture, Sport, Science and Technology: Grants-in-Aid for Scientific Research, 2

[75] Huett, J. B., Kalinowski, K. E., Moller, L., \& Huett, K. C. (2008). Improving the Motivation and Retention of Online Students Through the Use of ARCS-Based E-Mails. The Amer: Journal of Distance Education, 22, 159-176.

[76]Malik, S. (2014). Effectiveness of ARCS Model of Motivational Design to Overcome Non Completion Rate of Students in Distance Education. Turkish Online Journal of Distance Education TOJDE, 15(2), 194-200.

[77]Fatimah, N dan Abdullah, A. A. (2013). Pengaruh Strategi Motivasi Attention, Relevance, Confidence, Satisfaction (ARCS) dalam Model Pembelajaran Langsung Terhadap Hasil Belajar Siswa Pada Pokok Bahasan Listrik Dinamis di Kelas X SMA Negeri 18 Surabaya. Jurnal Inovasi Pendidikan Fisika, 2 (2) 75-77.

[78] Maya, S dan Evy (2014). Pengaruh Strategi ARCS (Attention, Relevance, Confidence, and Satisfaction) Terhadap Motivasi dan hasil Belajar TIK Siswa Kelas VIII di SMP Negeri 4 Negara. $e$ Journal Program Pascasarjana Universitas Pendidikan Ganesha Program Studi Teknologi Pembelajaran, 4, 1-9.

[79] Nugraha, I. G. N. W., Lasmawan, W., dan Tika, N. (2014). Pengaruh Strategi Pembelajaran ARCS (Attention, Relevance, Confidence, Satisfaction) Terhadap Hasil Belajar Siswa Dengan Kovariabel Motivasi Belajar Dalam Pembelajaran IPA Pada Siswa Kelas V SD Cerdas Mandiri. e-Journal Program Pascasarjana Universitas Pendidikan Ganesha Program Studi Pendidikan Dasar, 4, 1-10.

[80]Winaya, I. M. A., Lasmawan, W., \& Dantes, N. (2013). Pengaruh Model ARCS Terhadap Hasil Belajar Ditinjau dari Motivasi Belajar Siswa Pada Pembelajaran IPS di Kelas IV SD Chis Denpasar. Program Studi Pendidikan Dasar: e-Journal Program Pascasarjana Universitas Pendidikan Ganesha, 3. 